University of San Diego

Digital USD

Spring 5-23-2020

\title{
Empowering Newly Diagnosed Patients with Hypertension in Reducing Complications through Self-Managed Care
}

Ana Pacis

University of San Diego, apacis@sandiego.edu

Follow this and additional works at: https://digital.sandiego.edu/dnp

Part of the Nursing Commons

\section{Digital USD Citation}

Pacis, Ana, "Empowering Newly Diagnosed Patients with Hypertension in Reducing Complications through Self-Managed Care" (2020). Doctor of Nursing Practice Final Manuscripts. 137.

https://digital.sandiego.edu/dnp/137

This Doctor of Nursing Practice Final Manuscript is brought to you for free and open access by the Theses and Dissertations at Digital USD. It has been accepted for inclusion in Doctor of Nursing Practice Final Manuscripts by an authorized administrator of Digital USD. For more information, please contact digital@sandiego.edu. 


\title{
UNIVERSITY OF SAN DIEGO \\ Hahn School of Nursing and Health Science \\ DOCTOR OF NURSING PRACTICE
}

\begin{abstract}
Empowering Newly Diagnosed Patients with Hypertension in Reducing Complications through Self-Managed Care
\end{abstract}

by

Ana Pacis, BSN, RN

A Doctor of Nursing Practice Portfolio presented to the

FACULTY OF THE HAHN SCHOOL OF NURSING AND HEALTH SCIENCE UNIVERSITY OF SAN DIEGO

\author{
In partial fulfillment of the \\ requirements for the degree \\ DOCTOR OF NURSING PRACTICE
}

May 2020

Joseph Burkard, DNSc, CRNA, Faculty Advisor

Richard Mallo, MD, Clinical Mentor 


\section{Table of Contents}

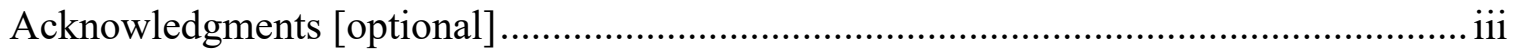

Opening Statement Purpose in Pursuing the DNP.............Error! Bookmark not defined. Documentation of Mastery of DNP Program Outcomes ............................................. 1

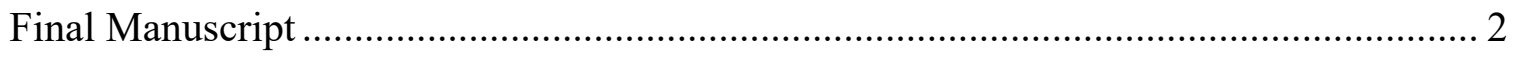

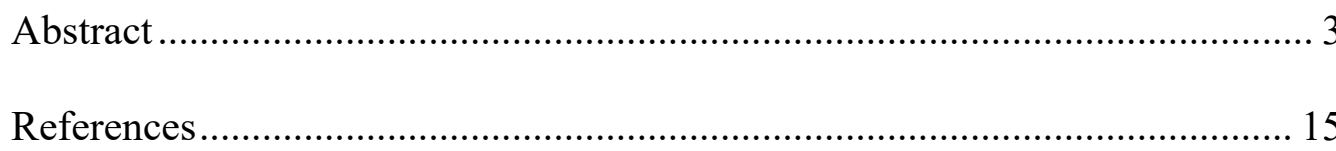

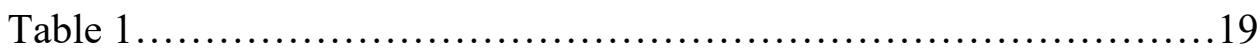

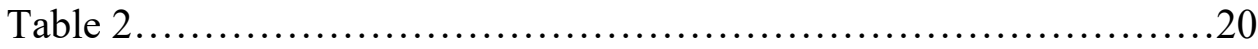

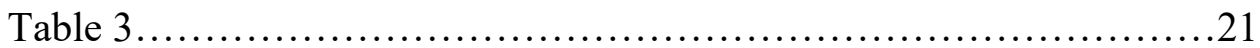

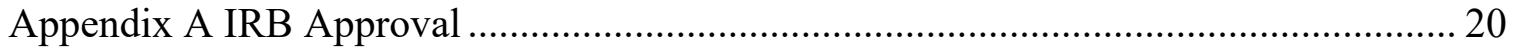

Appendix B Letter of Support from Clinical Site ................................................... 20

Appendix C Letter of acceptance to Conference ..................................23

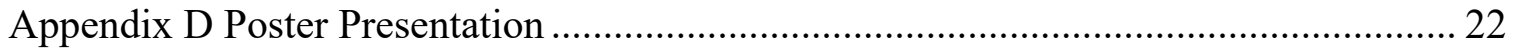

Appendix E DNP Program Outcomes Exemplars ......................................................... 24

Appendix F Certificates or Documentation of any Additional Certifications [if applicable]41 


\section{Acknowledgments}

First, I would like to thank God for His never-ending love and guidance in this journey. It has been a stressful and challenging three years and without His help, I don't think I would have made it in this program. I pray for His continuous gifts of wisdom, grace, and good health so I may continue to serve others in His name.

To my husband, the best partner and supporter I could ever have and dream of. Thank you for always bring there and helping me achieve my goals. Thank you for always being patient with me through the ups and downs while I completed this program. Thank you for everything and I will always love you.

To my beloved daughters whom I love dearly, Caitleen and Faith. You have given me your love, patience, and understanding and you have helped me laugh during difficult times. You and your dad are my rock. You all encouraged me to fight during this journey, inspired me to complete this program, and helped me achieve my dreams.

To my siblings, thank you for always being there even though we are all thousands of miles apart. I wish that we could all live close together, share more laughs, and create more memories.

To my Life Study group, especially to Ate Vangie and Marissa, who are always there listening to my problems and praying for me. To all my friends who continuously giving me support and advice, thank you for being there for me.

To Dr. Joseph Burkard, thank you for believing, guiding, and encouraging me in finishing this EBP project. You are always lending a hand, sharing your knowledge, and inspiring us all to make a change and promote a positive impact in nursing. 
I would like to acknowledge all the faculty and staff at Hahn School of Nursing at the University of San Diego. To Dr. Kevin Maxwell, Dr. Pedro Colio, Dr. Michelle Kabakibi, Dr. Razel Milo, Dr. Nicole Martinez, Dr. Karen Macauley, and Dr. K. Sue Hoyt, thank you for instructing all of us and setting a high standard for our education. I also would like to thank Dr. Donna Agan, for guiding me in analyzing the data in this EBP project. To all my clinical instructors and clinical mentors, thank you for sharing your knowledge and your constructive criticisms to make me a better NP in the future.

To Natalie Higgins from Graybill Urgent Care. Thank you for putting up with me, understanding my shortcomings during clinicals, sharing your knowledge, and teaching me. To all the staff at Graybill Medical Group clinic especially to Marlene, thank you for helping me in this DNP project. Lastly, to Dr. Richard Mallo, who gave me his full support and trained me, thank you so much. I could not have made it this far without your help. 
Documentation of Mastery of DNP Program Outcomes 


\section{Final Manuscript}

Empowering Newly Diagnosed Patients with Hypertension in Reducing Complications through

Self-Managed Care

Ana Pacis, BSN, RN

Joseph Burkard, DNSc, CRNA

Richard Mallo, MD

University of San Diego 


\begin{abstract}
Background: High blood pressure affects millions of people, including children and adults. According to the Centers for Disease Control and Prevention (CDC), about 1 in every 3 adults or approximately 75 million American adults are affected with high blood pressure. High blood pressure often does not cause any signs and symptoms, which is why it is also known as the "silent killer," and many people are not aware that they have elevated blood pressure (AHA, 2017). If high blood pressure is not controlled, it can lead to other heart diseases such as stroke. It can also cause other health problems, which can affect the eyes and kidneys.

Purpose of the Study: Individuals diagnosed with hypertension are at risk for developing complications due to a lack of knowledge and education on the importance and ways of managing their disease. The purpose of this project is to empower and educate newly diagnosed patients with hypertension on how to self-manage their disease to reduce complications. Lifestyle modifications such as exercise, adopting the dietary approach to stop hypertension (DASH) diet, reducing sodium intake, and medication adherence will all be included in the education.
\end{abstract}

Methods: Patients that were diagnosed within the past five (5) years, can speak and read in English or have an immediate family member that lives with the patient and can speak or read in English will be encouraged to join in this evidence-based practice project. Patients and their caregivers will be educated through a self-care model with a focus on medication adherence and lifestyle modifications as recommended by AHA, ACC, and JNC-8 guidelines. 
Results: This evidenced-based project showed a significant decrease of $9.71 \mathrm{mmHg}$ in systolic blood pressure (SBP) for those who adhere to taking their prescribed hypertensive medications. Those who followed the DASH diet showed an improvement in their SBP by $5.38 \mathrm{mmHg}$ within six (6) months.

Significance: Empowering patients with hypertension through self-managed care is essential in reducing complications. Adhering to lifestyle modifications such as the DASH diet, reducing sodium intake, and engaging in regular exercise, in addition to taking the prescribed hypertensive medications, are all significant factors in reducing the risk of high blood pressure. Increasing education, awareness, and counseling on managing their disease can lead to a reduction in SBP, which can eventually lead to a decrease in complications, mortality, and morbidity.

Key words: DASH diet, hypertension, high blood pressure, lifestyle modification, exercise, and medication adherence. 
Empowering Newly Diagnosed Patients with Hypertension in Reducing Complications through

\section{Self-Managed Care}

\section{Introduction}

Hypertension, also called high blood pressure, is when the force of blood pushing against the arterial wall is consistently high (American Heart Association, 2016). High blood pressure affects millions of people, including children and adults. According to the Centers for Disease Control and Prevention (CDC), about 1 in every 3 adults or approximately 75 million American adults are affected with high blood pressure. High blood pressure often does not cause any signs and symptoms, which is why it is also known as the "silent killer," and many people are not aware that they have elevated blood pressure (AHA, 2017). If high blood pressure is not controlled, it can lead to other heart diseases such as stroke. It can also affect the eyes, kidneys, and can cause other health problems.

Blood pressure is written in two numbers. The top number, known as systolic blood pressure or SBP, is the force of blood when the heartbeats and the diastolic blood pressure or DBP is the force of blood when the heart is at rest in between beats (AHA, 2017). Normal blood pressure for adults as defined by the American Heart Association's (AHA) new guidelines for hypertension is SBP below $120 \mathrm{mmHg}$ and a DBP of less than $80 \mathrm{mmHg}$. $120-129 \mathrm{mmHg}$ and less than $80 \mathrm{mmHg}$ DBP is considered elevated BP. Stage 1 hypertension is with SBP of 130$139 \mathrm{mmHg}$ and DBP of $80-89 \mathrm{mmHg}$. Stage 2 hypertension is those individuals with equal or greater than $140 \mathrm{mmHg}$ SBP and equivalent to or greater than 90 DBP (AHA, 2017). Lifestyle changes such as diet and exercise are recommended to prevent complications from high blood pressure. In some patients, a single blood pressure-lowering medication or a combination of 
prescribed antihypertensive medications may be necessary to control elevated blood pressure, especially for those individuals with stage 2 hypertension.

Several factors increase a person's risk of hypertension. A family history of high blood pressure, race or ethnicity, age, and gender are factors that cannot be modified or change. Factors that can be modified are weight, diet, physical inactivity, and medication compliance.

Currently, the Internal Medicine clinic of Richard Mallo, MD has numerous patients with hypertension, the exact number unknown. No current education materials are being used. Patients that were recently diagnosed in five (5) years or less, can speak and read in English or have an immediate family member that lives with the patient and can speak or read in English were encourage to join this project.

\section{Description of Evidence-Based Practice Project, Facilitators, and Barriers}

According to AHA, the American College of Cardiology (ACC), and CDC, high blood pressure is a contributing factor for stroke and heart disease, which are the two leading causes of death in the United States (CDC, 2016). Individuals diagnosed with high blood pressure are at risk for developing complications due to a lack of education on the importance and ways of managing their disease. High blood pressure management should include lifestyle modifications, medication adherence, and a follow-up appointment with their primary care provider (Go, et al. 2014). "Lifestyle modifications should be initiated in all patients with hypertension" (Go, et al. 2014). The relative decrease in SBP for lifestyle modifications ranges from 4-20 $\mathrm{mmHg}$. 4-9 $\mathrm{mmHg}$ for physical activity with at least 30 minutes of aerobic exercise such as brisk walking; 2-8 $\mathrm{mmHg}$ for lower sodium intake of less than 2,400 $\mathrm{mg}$ of sodium/day; $8-14 \mathrm{mmHg}$ for adopting the dietary approaches to stop hypertension (DASH) diet; and 5-20 mmHg/10 kg for 
maintaining a healthy body weight or keeping a body mass index of $18.5-24.9 \mathrm{~kg} / \mathrm{m} 2$ (Whelton, et al 2017).

Support and cooperation from Graybill Medical staff such as the medical assistants and Dr. Richard Mallo are of utmost importance. Barriers that were addressed with the stakeholders are time and availability of space or room.

The internal medicine clinic where this project was implemented has a very busy schedule, and each patient was allotted a time of 15 minutes per visit. Education and counseling were limited due to insufficient time. Another barrier was the availability of the room. Because of the high turn-around of the patient visit and the limited number of rooms, it was impossible to fully educate the patients on the importance and positive impact of lifestyle modifications and medication adherence in managing their disease. To supplement the lack of time and room availability, follow-up phone calls were made to each participant to reaffirm the teachings. Throughout this EBP project, it was also discovered that some patients were unwilling to change their negative habits due to hectic work and home life schedule, and thus, is another hindrance in improving their blood pressure and managing their disease.

\section{Evidence-Based Practice Model}

Dorothea Orem, a theorist in the field of nursing developed the self-care theory in 1959. She believed that an individual should be able to take care of themselves, be self-reliant, and be responsible for their own care. She also believed that it is necessary for an individual to be informed of potential health problems in order to promote self-care behaviors (currentnursing.com, 2012).

Hypertension is a chronic illness that affects individuals' overall health. It creates a burden, not only to the hypertensive patients but also to their families. According to Han, Lee, 
Commodore-Mensah, and Kim, in their study, an adequate self-care is important for blood pressure control. The self-care theory will guide this EBP project in educating and creating opportunities for the patients and their families, empowering them to take an active role in reducing complications from high blood pressure.

\section{Proposed Evidence-Based Solutions}

To show the rationality and strength of this proposed EBP project, literature reviews were used from different search engines such as CINAHL, PubMed, Cochrane, and Medline. Literature reviews varied from a randomized controlled study, review articles, a systematic review and meta-analysis review. A total of 25 articles were reviewed; six have been categorized according to the John Hopkins evidence level and quality guide.

A. Heagerty (2006) in his review of optimizing hypertension management in clinical practice states that "patient compliance with prescribed antihypertensive medications is poor and lifestyle advice is inadequate." Physicians guidance on the importance of lifestyle modifications may not be sufficient due to insufficient time, the low reimbursement rate for counseling, and physicians' skepticism on patients' willingness to transform negative habits into positive behavior (Heagerty, 2006). A.Heagerty added that educating and involving patients in managing their illness can increase compliance.

A systematic review and meta-analysis on DASH diet comparing sixty-five articles for full review with twenty articles included in the systematic review stated that "DASH diet interventions have significant improvements in systolic and diastolic BP along with significant reductions in total cholesterol and LDL concentrations" (Sacks et al. 2001). This literature review showed that the DASH diet has beneficial effects on the prevention and management of hypertension. 
Sodium is believed to be related to blood pressure elevation and other cardiovascular diseases. In a study that was published in The New England Journal of Medicine, Sacks, F.M. et al., showed that reducing salt intake in combination with DASH diet lowered SBP by 11.5 $\mathrm{mmHg}$ in participants with hypertension and $7.1 \mathrm{mmHg}$ in participants without hypertension. In another study, He, F.J., et al., publicized that reduction in salt intake to a recommended 2,300 milligrams (mg) per day by 2015-2020 Dietary Guidelines for Americans for four or more weeks will result in a decrease in blood pressure in both hypertensive and non-hypertensive individuals.

Regular physical activity can lower your systolic blood pressure by 4-9 mmHg according to AHA, ACC, and CDC guidelines. The Department of Health and Human Services recommends at least 150 minutes of moderate aerobic activity or 75 minutes of brisk walking a week, or a combination of both (Whelton et al. 2017). A meta-analysis review on the effect of aerobic exercise on blood pressure that included 54 clinical trials with a total number of 2419 participants showed a decrease of $3.84 \mathrm{mmHg}$ for SBP and $2.58 \mathrm{mmHg}$ for DBP (Whelton et al. 2002). In this study, results showed that blood pressure reduction might be independent of change in body weight since participants did not lose weight overall. However, despite the outcome that participants did not lose weight during this study, the reduction in blood pressure showed that a decrease in blood pressure due to aerobic exercise could reduce complications and death from cardiovascular disease (Whelton et al. 2002).

\section{Methods}

After receiving the approval from the University of San Diego Institutional Review Board (IRB) and the letter of support from Richard Mallo, MD of Graybill Medical Group Internal Medicine Clinic, recruitment and screening process of participants began. Inclusion criteria were a definite diagnosis of hypertension within the past five (5) years by a physician, participants' 
ability to speak and read in English or have an immediate family member that lives with the patient and can speak or read in English. A total of 61 patients with hypertension qualified and participated in this evidence-based project; age varied from 20 to 77 years old. Patients and their caregivers were educated through a self-care model with a focus on medication adherence and lifestyle modifications such as routine exercise, adopting the DASH diet, and low sodium intake as recommended by AHA, ACC, and JNC-8 guidelines.

Four variables were used for data collection. The first one was blood pressure reading. Each of the qualified participants was informed of the project either during their visit at the clinic or over the phone, and if interested, their BP during that visit or their latest BP reading during their last visit was used as a baseline. Second was their BMI, which was calculated based on their height and weight. A self-report exercise regimen was used next, and last but not the least, the participants were asked to answer 9 questions regarding their medication adherence using the Hilll-Bone Medication Adherence Scale (HB-MAS). Each of the participants was provided with written educational materials on HBP, DASH diet, and exercise guidelines as recommended by CDC and AHA.

The patient's activities were assessed from the $2^{\text {nd }}$ week to the $24^{\text {th }}$ week of this project. A phone call during the $2^{\text {nd }}$ week, followed by monthly until the fifth month were made to each participant to follow-up on their progress and adherence to the interventions provided. A face-toface session was done at the end of the project and a review of their written self-report was conducted.

Data were analyzed using the SPSS program; individual variables were compared using descriptive statistics; chi-square test was used for comparison of individual groups; and paired ttest for before and after the intervention. 


\section{Results}

As seen in Table 1, there is a significant increase in the number of participants between the pre- and post- interventions who include exercise activities as part of their lifestyle modifications $(\mathrm{P}<.01)$. The result also showed a higher participation among the participants in the DASH diet $(\mathrm{P}<.001)$. Finally, there was a great response in medication adherence, showing a statistically significant difference $(\mathrm{P}<.0376)$.

In Table 2, the data showed that with self-care model, after educating and empowering the participants, it resulted in a significant decrease in their systolic blood pressure. Those who were compliant in taking their prescribed blood pressure medications showed a significant decrease in their systolic blood pressure of $9.71 \mathrm{mmHg}$ within the six months period $(\mathrm{P}<.0376)$. Those who followed the DASH diet resulted a significant decrease in their SBP by $5.38 \mathrm{mmHg}$ $(\mathrm{P}<.001)$. Lastly, although those who exercise regularly showed a decrease in their systolic blood pressure but because the $\mathrm{P}$ value in this particular variable is $0.067(\mathrm{P}>.05)$, the data collected is not enough to be statistically significant.

The findings of this study also showed that participants who were non-adherent to their prescribed blood pressure medications are more likely to not exercise and therefore, no decrease in their SBP was noted $(\mathrm{P}>.05)$. While those who adhere to taking their prescribed blood pressure medications, together with following an exercise routine and DASH diet have shown to decrease their SBP by $6.869 \mathrm{mmHg}$ in six-month period $(\mathrm{P}<.001)$.

\section{Cost/Benefit Analysis}

This project incurred a minimal cost. The total expense was $\$ 124.00$, which include the folders and printing of questionnaire and informational flyers. No cost was incurred to the patient. 
In a study that was recently published in Journal of American Heart Association, it stated that "individuals with hypertension are estimated to face nearly $\$ 2000$ higher annual healthcare expenditure compared to non-hypertensive peers (Kirkland et al 2018). This means that investing in the prevention and management of hypertension, it will save our healthcare system an approximate $\$ 121,876$ per year just for the 61 patients who participated in this project. Please see Table 3 for further details and breakdown of the cost.

\section{Discussion}

Hypertension is among the diseases that can be controlled by taking an active role in selfcare activities. Lack of awareness about an individual's disease and knowing the importance of proper interventions, the hypertensive patients may not be compliant with their treatment. To control their high blood pressure in order to reduce the complications, it is important to identify their educational needs, empower them, and provide them with materials that would explain the importance of adhering to medication treatment and participating in proper interventions.

The self-care behavior in this EBP project focused on medication adherence and lifestyle modifications such as exercise, DASH diet, and low sodium intake. The study findings in this project indicated the effectiveness of lifestyle modifications and medication adherence in lowering the systolic blood pressure. This is consistent with a medication adherence study conducted in a primary care setting in Malaysia (Ramili et al. 2012). A systematic review with meta-analysis study on DASH diet showed a significant decrease in systolic blood pressure, which have confirmed the importance of lifestyle modifications in lowering blood pressure and reducing complications from hypertension (Siervo et al. 2014). 


\section{Practice Implications}

Empowering patients with hypertension through self-managed care is essential in reducing complications. Providing education, counseling, and increasing awareness on managing their disease, the anticipated outcome would be a reduction in blood pressure as outlined in the AHA and ACC hypertension clinical practice guidelines. As a result, individuals affected with high blood pressure will have a reduction in complications, which can eventually lead to a decrease in mortality, and morbidity.

\section{Limitations}

Participants in this EBP project were patients diagnosed with hypertension five (5) years or less. These participants were only recruited from one provider's clinic, which limit the number of qualified patients for the study. The clinic where this study was conducted has a very demanding schedule. As a result, a follow-up face to face session with the participants was a challenge. Additionally, knowledge deficit with hypertension combined with patients' unwillingness to change their negative habits due hectic work and home life schedule, patients had difficulty adhering to taking the prescribed medications and partaking in lifestyle modifications.

For future improvements of this project, an increase in the number of participants is highly encouraged, at least a year of assessing, educating, and evaluating the outcome would be an ideal to see a significant result statistically, and finally, a 10-15 minutes allotted time to do a face to face session to each participant for follow-up, investigation of challenges, and continuing education would be an ideal for the success of the project. 


\section{Conflicts of Interest}

The author have no conflicts of interest.

\section{Acknowledgements}

This work was supported by the University of San Diego and Graybill Medical Group

Internal Medicine Clinic. The author wishes to thank Dr. Richard Mallo for his full support and his staff for their great help with participant recruitment and data collection. 


\section{References}

American Heart Association (2016, October). What is high blood pressure? Retrieved from https:/www.heart.org/en/health-topics/high-blood-pressure/the-facts-about-high-bloodpressure/what-is-high-blood-pressure

American Heart Association (2017, November). Why high blood pressure is a "silent killer"? Retrieved from https://www.heart.org/en/health-topics/high-blood-pressure/why-highblood-pressure-is-a-silent-killer

Centers for Disease Control and Prevention (2016, June). High blood pressure in the United States. Retrieved from http://wwwcdc.gov/dhdsp/data_statistics/fact_sheets/fsbloodpressure.htm

Dearholt, S. L. \& Dang, D. (2012). Johns Hopkins nursing evidence-based practice: Model and Guidelines (2nd ed). Indianapolis, IN Sigma Theta Tau International

Go, A.S., Bauman, M., Coleman King, S.M., Foranow, G.C., Lawrence, W., Williams, K.A., \& Sanchez, E. (2014). An effective approach to high blood pressure control. A science advisory from the American Heart Association, the American College of Cardiology, and the Centers for Disease Control and Prevention. Hypertension. https://doi.org/10.1161/hyp.0000000000000003.

Han, H., Lee, H., Commodore-Mensah, Y., \& Kim, M. (2014). Development and validation of the hypertension self-care profile: A practical tool to measure hypertension self-care. Journal of Cardiovascular Nursing, 29(3). doi:10.1097/JCN.Ob013e3182a3fd46.

He, F.J., Li, J., \& MacGregor, G.A. (2013). Effect of longer term modest salt reduction on blood pressure: Cochrane systematic review and meta-analysis of randomized trials. The British Medical Journal, 346(1-15). 
Heagerty, A. (2006). Optimizing hypertension management in clinical practice. Journal of Human Hypertension, 20(841-849).

Melnyk, B.M., \& Fineout-Overholt, E. (2015). Evidence-based practice in nursing healthcare: A guide to best practice. ( $3^{\text {rd }}$ ed.). Wolters Kluwer Health/Lippincott Williams \& Wilkins.

Merriam-Webster. (n.d.). Merriam-Webster.com dictionary. Retrieved April 2020, from https://www.merriam-webster.com/

Sacks, F.M., Svetkey, L.P., Vollmer, W.M., Appel, L.J., Bray, G.A., Harsha, D., ... Lin, P. (2001). Effects on blood pressure of reduced dietary sodium and the dietary approaches to stop hypertension (DASH) diet. The New England Journal of Medicine, 344(1), 3-10.

Siervo, M., Lara, J., Chowdhury, S., Ashor, A., Oggioni, C., \& Mathers, J.C. (2015). Effects of the dietary approach to stop hypertension (DASH) diet on cardiovascular risk factors: a systematic review and meta-analysis. British Journal of Nutrition, 113(1-15)

Whelton, P.K., Carey, R.M., Aronow, W.S., Casey D.E. Jr., Collins, K.J., Dennison H.C., Wright, T.J. Jr. (2017). Guideline for the prevention, detection, evaluation, and management of high blood pressure in adults: a report of the American College of Cardiology/American Heart Association Task Force on Clinical Practice Guidelines. Hypertension. https://doi.org/10.1161/HYP/0000000000000065.

Whelton, S.P., Chin, A., Xin, X., and He, J. (2002). Effect of aerobic exercise on blood pressure: A meta-analysis of randomized, controlled trials. Annals of Internal Medicine, 136(7), 493-503. 
Table 1

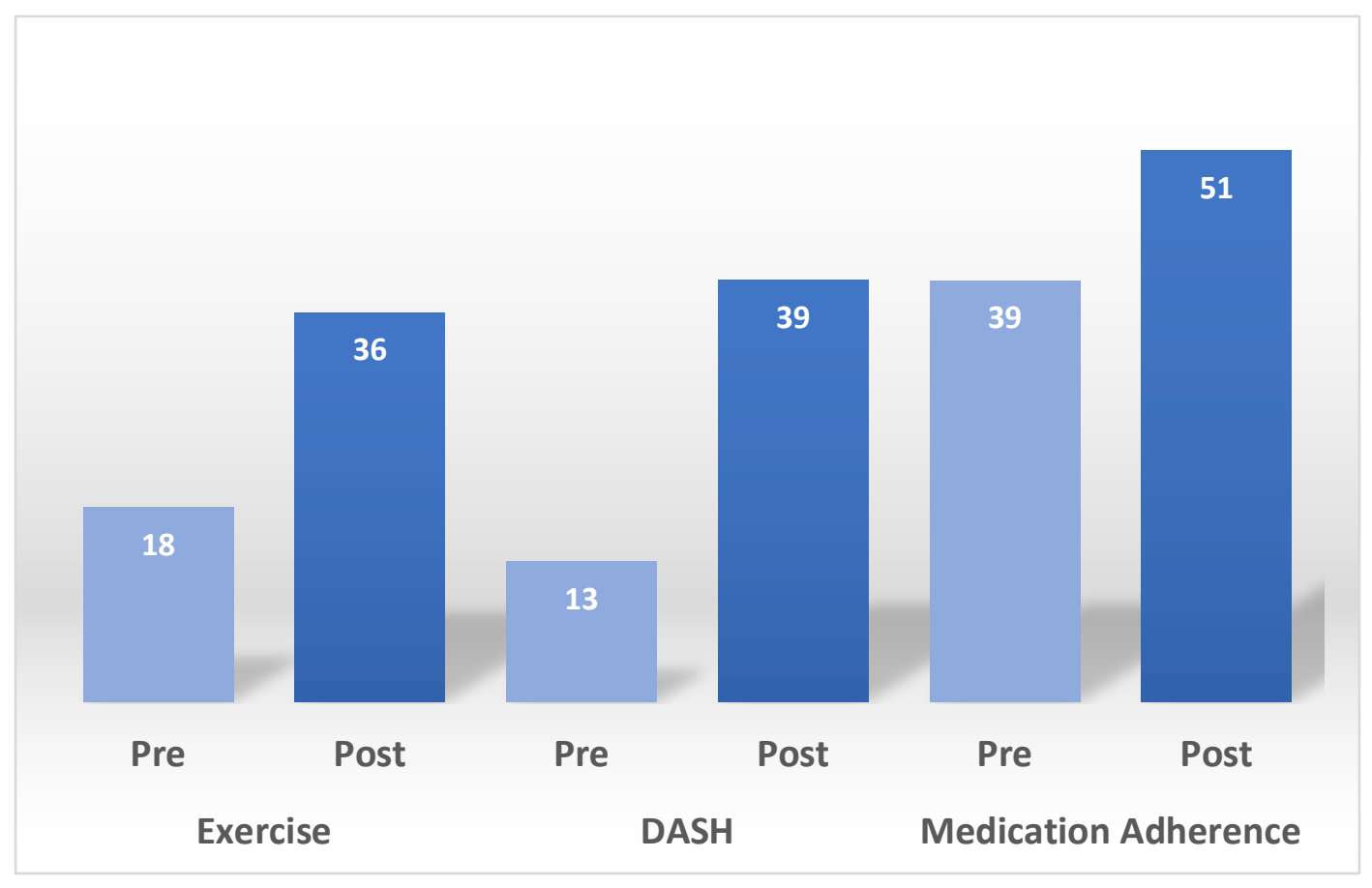


Table 2

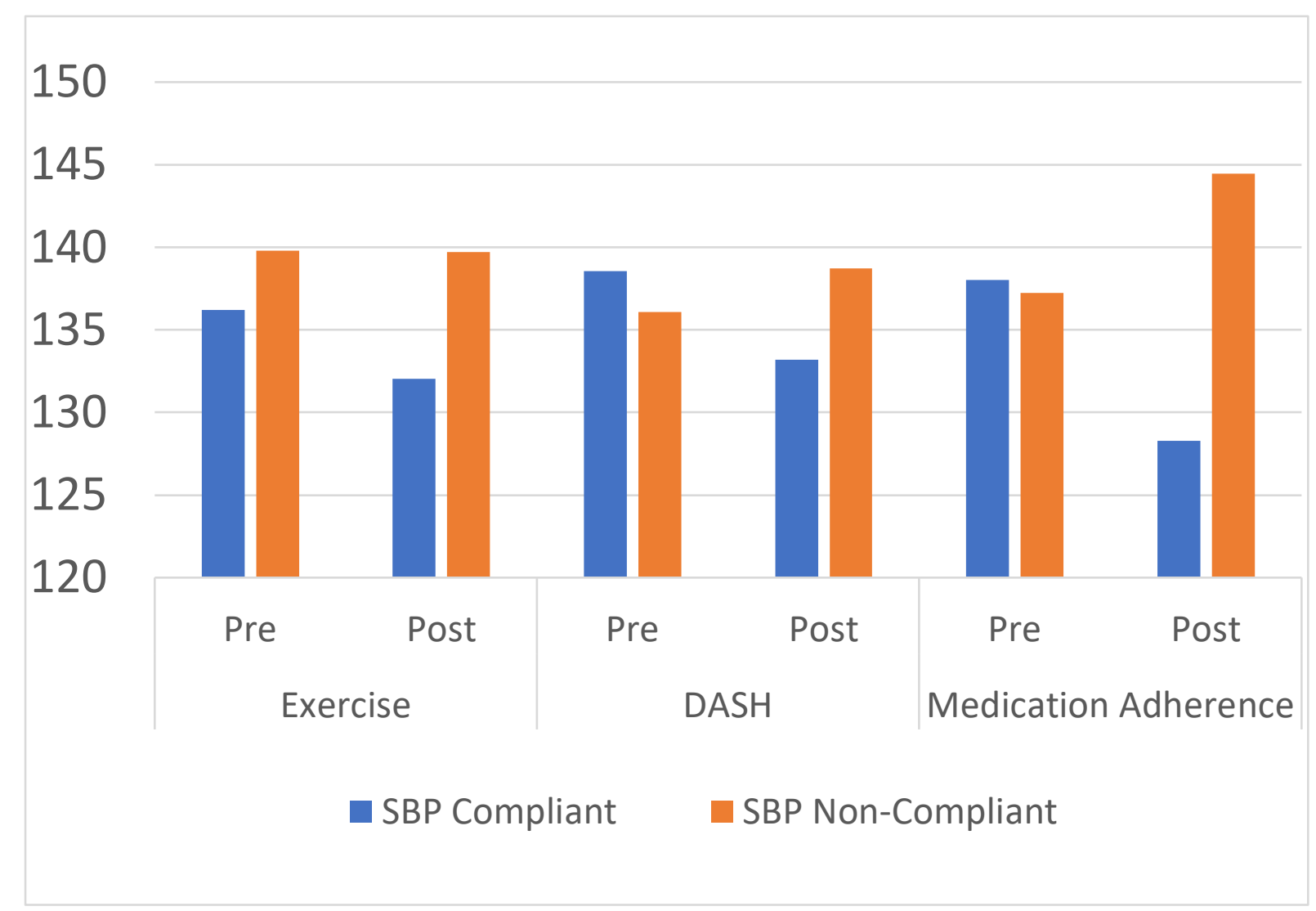


Table 3

\begin{tabular}{|c|c|c|}
\hline Resource & Cost & Rationale \\
\hline Education and Training & $\$ 0.00$ & $\begin{array}{l}\text { Completed during clinical } \\
\text { hours }\end{array}$ \\
\hline $\begin{array}{l}\text { Forms/Flyers } \\
620 \text { copies x } \$ 0.10\end{array}$ & $\$ 62.00$ & $\begin{array}{l}\text { Hill-Bone Medication } \\
\text { Adherence Questionnaire and } \\
\text { BP log form }\end{array}$ \\
\hline $\begin{array}{l}\text { Folders } \\
62 \times 0.10 / \text { folder }\end{array}$ & $\$ 62.00$ & $\begin{array}{l}\text { Folders for the educational } \\
\text { materials provided to the } \\
\text { participants }\end{array}$ \\
\hline Total cost & $\$ 124.00$ & \\
\hline Benefit & Cost & Rationale \\
\hline $\begin{array}{l}\text { Annual healthcare } \\
\text { expenditure in hypertensive } \\
\text { patients }=\$ 2000 \text { per person } \mathrm{x} \\
61 \text { patients }=\$ 122,000 / \mathrm{yr}\end{array}$ & $\$ 122,000$ & \\
\hline Cost Benefit Analysis & $\begin{array}{l}\text { Savings in healthcare costs }= \\
\$ 121,876 \text { per year }\end{array}$ & \\
\hline
\end{tabular}


Appendix A

IRB Approval

Date: $5-20-2019$

IRB \#: IRB-2019-444

Title: Empowering Newly Diagnosed Patients with Hypertension in a Primary Care Setting in Reducing Complications through Self-Managed Care

Creation Date: 5-14-2019

End Date: $5-13-2020$

Status: Approved

Principal Investigator: Ana Pacis

Review Board: USD IRB

Sponsor:

\section{Study History}

\begin{tabular}{ll}
\hline Submission Type Initial $\quad$ Review Type Exempt $\quad$ Decision Exempt \\
\hline
\end{tabular}

Key Study Contacts

\begin{tabular}{lll}
\hline Member Ana Pacis & Role Principal Investigator & Contact apacis@sandiego.edu \\
\hline Member Joseph Burkard & Role Primary Contact & Contact jburkard@sandiego.edu \\
\hline Member Joseph Burkard & Role Co-Principal Investigator & Contact jburkard@sandiego.edu \\
\hline
\end{tabular}




\section{Appendix B}

\section{Letter of Support from Clinical Site}

$\begin{aligned} & \text { Floyd Farley } \\ & \text { Chief Executive Officer }\end{aligned}$
$\begin{aligned} & \text { Alejandro Paz, MD, MPH } \\ & \text { President }\end{aligned}$
ESCONDIDO | OCEANSIDE | SAN MARCOS | VISTA | SABRE SPRINGS | RAMONA | VALLEY CENTER | FALLBROOK | TEMECULA | MURRIETA

May 14, 2019

To:

Institutional Review Board, University of San Diego

From:

Richard Mallo, MD

Re:

Doctor of Nursing Practice Capstone Project

Ana Pacis, a Doctor of Nursing Practice student from University of San Diego has been doing a clinical residency at Graybill Medical Group since Fall 2018.

Ms. Pacis is requesting the use of data from this clinical residency for her evidence-base project "Empowering Newly Diagnosed Patients with Hypertension in a Primary Care Setting in Reducing Complications through SelfManaged Care" and for possible presentations and publications.

I am supportive of Ms. Pacis in this EBP project and will work with her in developing the clinical significance of this project.

If you have any questions, please do not hesitate to contact me at rmallo@graybill.org.

Sincerelv.

Richard Mallo, MD 


\title{
Appendix C
}

\section{Letter of Acceptance to Conference}

Dear Presenter,

Thank you for submitting an abstract to present a poster at CANP's $43^{\text {rd }}$ Annual Educational Conference taking place March 19-21. 2020 in Riverside. Congratulations, your poster has been accepted.

Poster presenters will be assigned a specific presentation time within one of the following time slots:

Thursday, March 19

- 7:45-8:15 a.m.

- $10: 15-11: 15$ a.m.

Friday, March 20

- $7: 30-8: 15$ a.m.

- 10:30 - 11:15 a.m.

Poster presenters are required to register for at least the day of the conference they are presenting. However, we encourage you to register and attend the entire conference. Additional information including specific presentation times will be sent to poster presenters later this month. Please let me know if you have any questions.

\author{
Erin Meyer \\ Events \& Education Director \\ 1415 L Street, Suite 1000 \\ Sacramento, CA 95814 \\ 916 441-1361 \\ canpweb.org
}




\section{Appendix D}

\section{Poster Presentation}

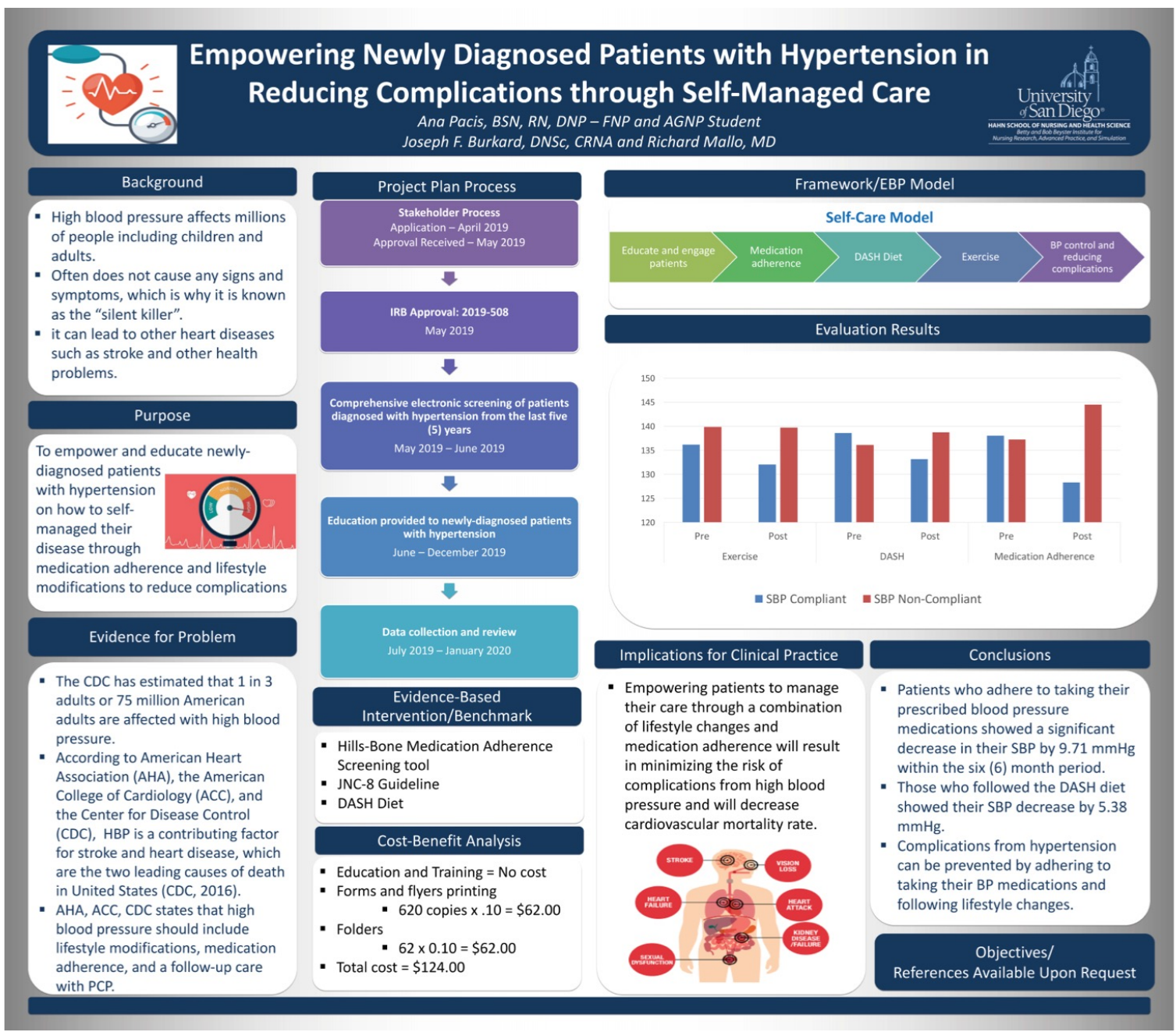




\section{Appendix E}

DNP Exemplars

AACN DNP Essentials/NONPF Competencies/USD DNP Program Outcomes Exemplars

\begin{tabular}{|c|c|c|}
\hline $\begin{array}{l}\text { AACN DNP Essentials \& } \\
\text { NONPF Competencies }\end{array}$ & $\begin{array}{c}\text { USD DNP Program } \\
\text { Objectives }\end{array}$ & $\begin{array}{c}\text { Exemplars } \\
\text { Provide bulleted exemplars } \\
\text { that demonstrates achievement } \\
\text { of each objective }\end{array}$ \\
\hline $\begin{array}{l}\text { DNP Essential I: Scientific } \\
\text { Underpinnings for Practice } \\
\text { NONPF: Scientific } \\
\text { Foundation Competencies } \\
\text { The scientific foundation of } \\
\text { nursing practice has expanded } \\
\text { and includes a focus on both } \\
\text { the natural and social sciences } \\
\text { including human biology, } \\
\text { genomics, science of } \\
\text { therapeutics, psychosocial } \\
\text { sciences, as well as the science } \\
\text { of complex organizational } \\
\text { structures. In addition, } \\
\text { philosophical, ethical, and } \\
\text { historical issues inherent in the } \\
\text { development of science create a } \\
\text { context for the application of } \\
\text { the natural and social sciences. }\end{array}$ & $\begin{array}{l}\text { 2. Synthesize nursing and } \\
\text { other scientific and ethical } \\
\text { theories and concepts to } \\
\text { create a foundation for } \\
\text { advanced nursing practice. }\end{array}$ & $\begin{array}{l}\text { Fall } 2017 \\
\text { - } \\
\text { Atilized Roy } \\
\text { Humantion model and } \\
\text { Theory of Paterson and } \\
\text { Zderad to guide PICO } \\
\text { question in Evidence- } \\
\text { Based Practice } \\
\text { Presentation } \\
\text { (DNPC626) } \\
\text { Spring 2018 } \\
\text { - Driver diagram model } \\
\text { used to outline EBP } \\
\text { Effective Management } \\
\text { of Pain for hospice } \\
\text { patients (DNPC626) } \\
\text { Plan-Do-Study-Act } \\
\text { (PDSA) Model } \\
\text { selected to guide DNP } \\
\text { EBP project to } \\
\text { improve quality care } \\
\text { (DNPC626; also } \\
\text { applies to 4,5,6,7, and } \\
\text { 8) } \\
\text { Utilized and } \\
\text { distributed evidence- } \\
\text { based research in } \\
\text { Complementary and } \\
\text { Alternative Medicine } \\
\text { Modalities } \\
\text { Presentation: Tea Tree } \\
\text { Oil (ANPC523) }\end{array}$ \\
\hline
\end{tabular}




\begin{tabular}{|c|c|c|}
\hline $\begin{array}{l}\text { AACN DNP Essentials \& } \\
\text { NONPF Competencies }\end{array}$ & $\begin{array}{l}\text { USD DNP Program } \\
\text { Objectives }\end{array}$ & $\begin{array}{c}\text { Exemplars } \\
\text { Provide bulleted exemplars } \\
\text { that demonstrates achievement } \\
\text { of each objective }\end{array}$ \\
\hline & & $\begin{array}{l}\text { Summer } 2018 \\
\text { - } \\
\text { Reflected on current } \\
\text { change management } \\
\text { skills including } \\
\text { evidence-based } \\
\text { research in discussion } \\
\text { boards (DPNC630) } \\
\text { - } \\
\text { Completed narrative } \\
\text { reflection on clinical } \\
\text { experiences (DNPC } \\
\text { 610) } \\
\text { Fall 2018 } \\
\text { - Learned about } \\
\text { principles of Primary } \\
\text { Care and what it } \\
\text { encompasses (NPTC } \\
\text { 602) } \\
\text { Applied theories of } \\
\text { primary care and acute } \\
\text { care nursing to clinical } \\
\text { experiences (NPTC } \\
\text { 602) } \\
\text { Spring 2019 } \\
\text { Used Orem's Self-Care } \\
\text { Theory to guide my } \\
\text { DNP project on } \\
\text { empowering } \\
\text { hypertensive patients } \\
\text { in reducing } \\
\text { complications through } \\
\text { self-managed care } \\
\text { (NPTC 605 and 535; } \\
\text { also applies to } \\
\text { Examplar 8) } \\
\text { Summer 2019 } \\
\text { Used SBIRT to } \\
\text { understand how to help } \\
\text { treatment of } \\
\text { adolescents with }\end{array}$ \\
\hline
\end{tabular}




\begin{tabular}{|c|c|c|}
\hline $\begin{array}{l}\text { AACN DNP Essentials \& } \\
\text { NONPF Competencies }\end{array}$ & $\begin{array}{c}\text { USD DNP Program } \\
\text { Objectives }\end{array}$ & $\begin{array}{c}\text { Exemplars } \\
\text { Provide bulleted exemplars } \\
\text { that demonstrates achievement } \\
\text { of each objective }\end{array}$ \\
\hline & & $\begin{array}{l}\text { addiction (NPTC 605; } \\
\text { also applies to } \\
\text { exemplar 8) } \\
\text { - Applied the theories of } \\
\text { primary care and acute } \\
\text { care nursing to clinical } \\
\text { experiences in Internal } \\
\text { Medicine clinic, } \\
\text { Endocrinologist clinic } \\
\text { and Urgent Care clinic } \\
\text { (NPTC } 605 \text { \& NPTC } \\
\text { 535) } \\
\text { Fall 2019 } \\
\text { - Applied the theories of } \\
\text { primary care and acute } \\
\text { care nursing to clinical } \\
\text { experiences in Internal } \\
\text { Medicine clinic, } \\
\text { Cardiology clinic and } \\
\text { Urgent Care clinic } \\
\text { (NPTC 608) }\end{array}$ \\
\hline $\begin{array}{l}\text { DNP Essential II: } \\
\text { Organizational \& System } \\
\text { Leadership for Quality } \\
\text { improvement and Systems } \\
\text { Thinking } \\
\text { NONPF: Leadership } \\
\text { Competencies/Health } \\
\text { Delivery System } \\
\text { Competencies } \\
\text { Advanced nursing practice } \\
\text { includes an organizational and } \\
\text { systems leadership component } \\
\text { that emphasizes practice, } \\
\text { ongoing improvement of health } \\
\text { outcomes, and ensuring patient } \\
\text { safety. Nurses should be } \\
\text { prepared with sophisticated }\end{array}$ & $\begin{array}{l}\text { 5. Design, implement, and } \\
\text { evaluate ethical health care } \\
\text { delivery systems and } \\
\text { information systems that } \\
\text { meet societal needs and } \\
\text { ensure accountability for } \\
\text { quality outcomes. }\end{array}$ & $\begin{array}{l}\text { Spring } 2018 \\
\text { - } \\
\text { Conducted needs } \\
\text { assessment of target } \\
\text { population and } \\
\text { designed quality } \\
\text { improvement project } \\
\text { based on measures and } \\
\text { evaluation of care } \\
\text { outcome (DNPC } 626, \\
\text { also applies to essential } \\
5,6, \text { and } 7 \text { ) } \\
\text { Summer } 2018 \\
\text { - } \\
\text { DNPC } 626 \text { learning on } \\
\text { how to complete } \\
\text { quality improvement } \\
\text { practices to improve } \\
\text { protocols and health } \\
\text { outcomes }\end{array}$ \\
\hline
\end{tabular}




\begin{tabular}{|c|c|c|}
\hline $\begin{array}{l}\text { AACN DNP Essentials \& } \\
\text { NONPF Competencies }\end{array}$ & $\begin{array}{c}\text { USD DNP Program } \\
\text { Objectives }\end{array}$ & $\begin{array}{c}\text { Exemplars } \\
\text { Provide bulleted exemplars } \\
\text { that demonstrates achievement } \\
\text { of each objective }\end{array}$ \\
\hline $\begin{array}{l}\text { expertise in assessing } \\
\text { organizations, identifying } \\
\text { system's issues, and facilitating } \\
\text { organization-wide changes in } \\
\text { practice delivery. This also } \\
\text { requires political skills, systems } \\
\text { thinking, and the business and } \\
\text { financial acumen needed for } \\
\text { the analysis of the practice } \\
\text { quality and costs. }\end{array}$ & & $\begin{array}{l}\text { Learned to guide care } \\
\text { and referrals based on } \\
\text { health insurance, while } \\
\text { also contemplating the } \\
\text { option of pro-bono } \\
\text { health information or } \\
\text { visits (DNPC 610) } \\
\text { - Developed a business } \\
\text { proposal to implement } \\
\text { an EHR system in } \\
\text { order to meet } \\
\text { meaningful use criteria } \\
\text { and advance } \\
\text { technology to increase } \\
\text { productivity and } \\
\text { quality of patient care } \\
\text { (DNPC 653) } \\
\text { Apply principle of } \\
\text { health care finance, } \\
\text { needs assessment, } \\
\text { strategic planning } \\
\text { models, and SWOT } \\
\text { analysis in order to } \\
\text { develop a health care } \\
\text { product proposal } \\
\text { regarding EHR on a } \\
\text { video platform (DNPC } \\
\text { 653) }\end{array}$ \\
\hline & & 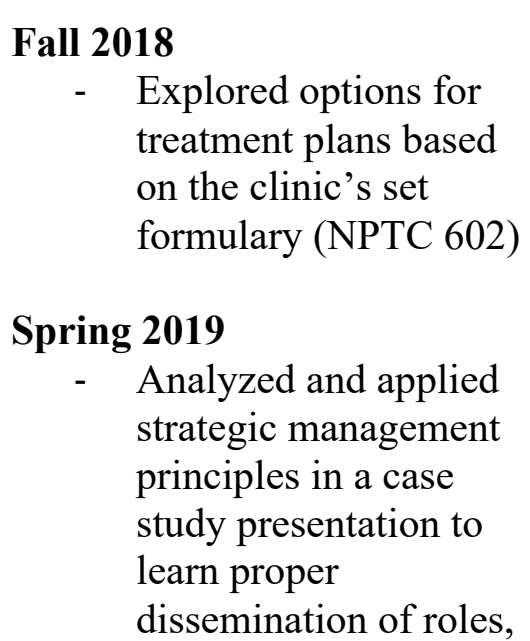 \\
\hline
\end{tabular}




\begin{tabular}{|c|c|c|}
\hline $\begin{array}{l}\text { AACN DNP Essentials \& } \\
\text { NONPF Competencies }\end{array}$ & $\begin{array}{c}\text { USD DNP Program } \\
\text { Objectives }\end{array}$ & $\begin{array}{c}\text { Exemplars } \\
\text { Provide bulleted exemplars } \\
\text { that demonstrates achievement } \\
\text { of each objective }\end{array}$ \\
\hline & & $\begin{array}{l}\text { planning for workplace } \\
\text { or health-care issues, } \\
\text { and advocate for } \\
\text { change (DNPC 626, } \\
\text { also applies to DNP } \\
\text { essentials } 4,5,6,7, \\
\text { and } 8 \text { ) ) } \\
\text { - Learned the ability to } \\
\text { differentiate insurance } \\
\text { coverage for } \\
\text { prescribed treatment } \\
\text { for example, having to } \\
\text { split up prescriptions } \\
\text { so insurance will cover } \\
\text { the medication (NPTC } \\
\text { 604) } \\
\text { Explored options for } \\
\text { treatment plans within } \\
\text { various health care } \\
\text { insurance plans and } \\
\text { providers (NPTC 604) } \\
\text { Explored options for } \\
\text { treatment plan for } \\
\text { prescribed medications } \\
\text { based on insurance } \\
\text { plans and coverage } \\
\text { (NPTC 604) } \\
\text { Summer 2019 } \\
\text { Learned about how } \\
\text { insurance limits the } \\
\text { availability of } \\
\text { medications and } \\
\text { treatments for patients } \\
\text { (NPTC 605 \& 535) } \\
\text { Learned how insurance } \\
\text { inhibits patients from } \\
\text { seeing certain } \\
\text { providers who are not } \\
\text { covered under the } \\
\text { insurance (NPTC } 605 \\
\text { \&35) }\end{array}$ \\
\hline
\end{tabular}




\begin{tabular}{|c|c|c|}
\hline $\begin{array}{l}\text { AACN DNP Essentials \& } \\
\text { NONPF Competencies }\end{array}$ & $\begin{array}{c}\text { USD DNP Program } \\
\text { Objectives }\end{array}$ & $\begin{array}{c}\text { Exemplars } \\
\text { Provide bulleted exemplars } \\
\text { that demonstrates achievement } \\
\text { of each objective }\end{array}$ \\
\hline & & 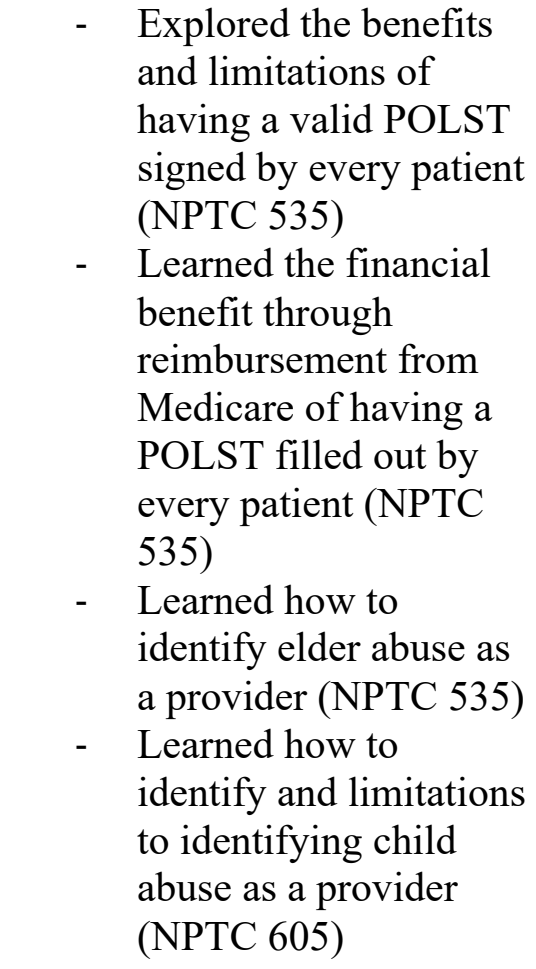 \\
\hline $\begin{array}{l}\text { DNP Essential III: Clinical } \\
\text { Scholarship \& Analytical } \\
\text { Methods for Evidence-Based } \\
\text { Practice } \\
\text { NONPF: Quality } \\
\text { Competencies/Practice } \\
\text { Inquiry Competencies } \\
\text { Scholarship and research are } \\
\text { the hallmarks of doctoral } \\
\text { education. Although basic } \\
\text { research is viewed as the first } \\
\text { and most essential form of } \\
\text { scholarly activity, an enlarged } \\
\text { perspective of scholarship has } \\
\text { emerged through alternative } \\
\text { paradigms that involve more } \\
\text { than discovery of new } \\
\text { knowledge. These paradigms } \\
\text { recognize: (2) the scholarship }\end{array}$ & $\begin{array}{l}\text { 4. Incorporate research into } \\
\text { practice through critical } \\
\text { appraisal of existing } \\
\text { evidence, evaluating } \\
\text { practice outcomes, and } \\
\text { developing evidence-based } \\
\text { practice guidelines. }\end{array}$ & $\begin{array}{l}\text { Fall } 2017 \\
\text { - } \\
\text { Synthesized and } \\
\text { completed evidence- } \\
\text { based literature review } \\
\text { on the need of order } \\
\text { sets for inpatients } \\
\text { nearing end of life } \\
\text { (DNPC611) } \\
\text { - } \\
\text { Utilized evidence- } \\
\text { based articles for the } \\
\text { improvement of patient } \\
\text { care and outcomes } \\
\text { (DNPC 611) } \\
\text { Spring } 2018 \\
\text { - Completed } \\
\text { complementary and } \\
\text { alternative medicine } \\
\text { research project on the } \\
\text { use of Tea Tree Oil }\end{array}$ \\
\hline
\end{tabular}




\begin{tabular}{|c|c|c|}
\hline $\begin{array}{l}\text { AACN DNP Essentials \& } \\
\text { NONPF Competencies }\end{array}$ & $\begin{array}{c}\text { USD DNP Program } \\
\text { Objectives }\end{array}$ & $\begin{array}{c}\text { Exemplars } \\
\text { Provide bulleted exemplars } \\
\text { that demonstrates achievement } \\
\text { of each objective }\end{array}$ \\
\hline $\begin{array}{l}\text { of discovery and integration } \\
\text { "reflects the investigative and } \\
\text { synthesizing traditions of } \\
\text { academic life;" (2) scholars } \\
\text { give meaning to isolated facts } \\
\text { and making connections across } \\
\text { disciplines through the } \\
\text { scholarship of integration; and } \\
\text { (3) the scholar applies } \\
\text { knowledge to solve a problem } \\
\text { via the scholarship of } \\
\text { application that involves the } \\
\text { translation of research into } \\
\text { practice and dissemination and } \\
\text { integration of new knowledge. }\end{array}$ & & $\begin{array}{l}\text { Quality Improvement } \\
\text { project on effective } \\
\text { delivery of pain } \\
\text { management for } \\
\text { hospice patients in } \\
\text { home-based setting } \\
\text { (DNPC 626; also } \\
\text { applies to DNP } \\
\text { Essential 2) } \\
\text { Summer } 2018 \\
\text { Researched the } \\
\text { benefits of mindfulness } \\
\text { and how to teach this } \\
\text { to patients to increase } \\
\text { QoL (NPTC 610; also } \\
\text { applies to DNP } \\
\text { essential 5, 7, and 8) }\end{array}$ \\
\hline & & $\begin{array}{l}\text { Fall } 2018 \\
\text { - } \\
\text { Conducted an } \\
\text { evidence-based lit } \\
\text { review on } 10 \text { diferent } \\
\text { pathophysiological } \\
\text { conditions for Grand } \\
\text { Rounds Presentations } \\
\text { (APNC 520) } \\
\text { - } \quad \text { Lit review on effects of } \\
\text { sleep deprivation } \\
\text { (DNPC 622) } \\
\text { Lit review on } \\
\text { Parkinson Disease } \\
\text { (DNPC 622) } \\
\text { Lit review on } \\
\text { Women's health } \\
\text { Screenings (NPTC } \\
\text { 602) } \\
\text { Reviewed evidence } \\
\text { based immunizations } \\
\text { schedules and } \\
\text { indications for infants, } \\
\text { children, women, men, }\end{array}$ \\
\hline
\end{tabular}




\begin{tabular}{|c|c|c|}
\hline $\begin{array}{l}\text { AACN DNP Essentials \& } \\
\text { NONPF Competencies }\end{array}$ & $\begin{array}{l}\text { USD DNP Program } \\
\text { Objectives }\end{array}$ & $\begin{array}{c}\text { Exemplars } \\
\text { Provide bulleted exemplars } \\
\text { that demonstrates achievement } \\
\text { of each objective }\end{array}$ \\
\hline & & $\begin{array}{l}\text { adults, and geriatric } \\
\text { populations (NPTC } \\
\text { 602) } \\
\text { Researched Lit review } \\
\text { on Pathogenesis of } \\
\text { Childhood Asthma } \\
\text { (DNPC 622) } \\
\text { - Learned Mediterranean } \\
\text { Diet and effects on } \\
\text { overall health and heart } \\
\text { and metabolic disease } \\
\text { (NPTC 602) } \\
\text { Learned TLC } \\
\text { (Therapeutic Lifestyle } \\
\text { Changes) Diet and } \\
\text { effects on overall } \\
\text { health and heart and } \\
\text { metabolic disease } \\
\text { (NPTC 602) } \\
\text { Spring 2019 } \\
\text { Researched Lit review } \\
\text { on Diabetes Insipidus } \\
\text { (NPTC 604) } \\
\text { Researched Lit review } \\
\text { on Pneumonia (NPTC } \\
\text { 604) } \\
\text { Summer 2019 } \\
\text { Conducted literature } \\
\text { review on Alzheimers } \\
\text { and Dementia (NPTC } \\
\text { 535) } \\
\text { Conducted literature } \\
\text { review on medications } \\
\text { for older adults and } \\
\text { learned Beer's List } \\
\text { (NPTC 535) } \\
\text { Conducted literature } \\
\text { review on } \\
\text { complimentary } \\
\text { alternative medications }\end{array}$ \\
\hline
\end{tabular}




\begin{tabular}{|c|c|c|}
\hline $\begin{array}{l}\text { AACN DNP Essentials \& } \\
\text { NONPF Competencies }\end{array}$ & $\begin{array}{c}\text { USD DNP Program } \\
\text { Objectives }\end{array}$ & $\begin{array}{c}\text { Exemplars } \\
\text { Provide bulleted exemplars } \\
\text { that demonstrates achievement } \\
\text { of each objective }\end{array}$ \\
\hline & & $\begin{array}{ll}\text { for older adults (NPTC } \\
\text { 535) } \\
\text { - } \\
\text { Conducted literature } \\
\text { review on elder abuse } \\
\text { in older adults (NPTC } \\
\text { 535) } \\
\text { - } \\
\text { Conducted a literature } \\
\text { review on } \\
\text { Postmenopause in } \\
\text { women (NPTC 605) } \\
\text { - } \quad \text { Conducted a literature } \\
\text { review on Polycystic } \\
\text { Ovarian Syndrome } \\
\text { (NPTC 605) } \\
\text { Conducted a lit review } \\
\text { on abnormal uterine } \\
\text { bleeding (NPTC 605) }\end{array}$ \\
\hline $\begin{array}{l}\text { DNP Essential IV: } \\
\text { Information } \\
\text { Systems/Technology \& } \\
\text { Patient Care Technology for } \\
\text { Improvement \& } \\
\text { Transformation of Health } \\
\text { Care } \\
\text { NONPF: Technology \& } \\
\text { Information Literacy } \\
\text { Competencies } \\
\text { DNP graduates are } \\
\text { distinguished by their abilities } \\
\text { to use information } \\
\text { systems/technology to support } \\
\text { and improve patient care and } \\
\text { health care systems, and } \\
\text { provide leadership within } \\
\text { health care systems and/or } \\
\text { academic settings. Knowledge } \\
\text { and skills related to } \\
\text { information systems/technology } \\
\text { and patient care technology }\end{array}$ & $\begin{array}{l}\text { 7. Incorporate ethical } \\
\text { regulatory, and legal } \\
\text { guidelines in the delivery } \\
\text { of health care and the } \\
\text { selection, use, and } \\
\text { evaluation of information } \\
\text { systems and patient care } \\
\text { technology. }\end{array}$ & $\begin{aligned} & \text { Fall } 2017 \\
&- \text { Obtained Biomedical } \\
& \text { Research Human } \\
& \text { Certification - } \\
& \text { Basic/Refresher } \\
& \text { Course through CITI } \\
& \text { (DNPC625) } \\
& \\
& \text { Summer } 2018 \\
& \text { - } \text { Discussed } \\
& \text { implementation of } \\
& \text { EHR systems } \\
& \text { including evidence- } \\
& \text { based research in } \\
& \text { discussion boards } \\
& \text { (DPNC653) } \\
& \\
& \text { Spring } 2019 \\
& \text { - } \\
& \text { Obtained USD IRB } \\
& \text { approval for DNP EBP } \\
& \text { project (DNPC 630) } \\
& \text { Obtained Graybill } \\
& \text { Medical Group } \\
& \text { Internal Medicine }\end{aligned}$ \\
\hline
\end{tabular}




\begin{tabular}{|c|c|c|}
\hline $\begin{array}{l}\text { AACN DNP Essentials \& } \\
\text { NONPF Competencies }\end{array}$ & $\begin{array}{c}\text { USD DNP Program } \\
\text { Objectives }\end{array}$ & $\begin{array}{c}\text { Exemplars } \\
\text { Provide bulleted exemplars } \\
\text { that demonstrates achievement } \\
\text { of each objective }\end{array}$ \\
\hline $\begin{array}{l}\text { prepare the DNP graduates } \\
\text { apply new knowledge, manage } \\
\text { individual and aggregate level } \\
\text { information, and assess the } \\
\text { efficacy of patient care } \\
\text { technology appropriate to a } \\
\text { specialized area of practice } \\
\text { along with the design, } \\
\text { selection, and use of } \\
\text { information systems/technology } \\
\text { to evaluate programs of care, } \\
\text { outcomes of care, and care } \\
\text { systems. Information } \\
\text { systems/technology provide a } \\
\text { mechanism to apply budget and } \\
\text { productivity tools, practice } \\
\text { information systems and } \\
\text { decision supports, and web- } \\
\text { based learning or intervention } \\
\text { tools to support and improve } \\
\text { patient care. }\end{array}$ & & $\begin{array}{l}\text { Clinic approval and } \\
\text { support for DNP EBP } \\
\text { project (DNPC 630) } \\
\text { - } \text { DNP project } \\
\text { implementation } \\
\text { (DNPC 686) } \\
\text { Summer 2019, Fall 2019 } \\
\text { - } \quad \text { Implementation of } \\
\text { DNP project at Dr. } \\
\text { Mallo's Internal } \\
\text { Medicine clinic }\end{array}$ \\
\hline $\begin{array}{l}\text { DNP Essential V: Health } \\
\text { Care Policy for Advocacy in } \\
\text { Health Care } \\
\text { NONPF: Policy Competencies } \\
\text { Health care policy, whether } \\
\text { created through governmental } \\
\text { actions, institutional decision- } \\
\text { making, or organizational } \\
\text { standards, creates a framework } \\
\text { that can facilitate or impede the } \\
\text { delivery of health care services } \\
\text { or the ability of the provider to } \\
\text { engage in practice to address } \\
\text { health care needs. Engagement } \\
\text { in the process of policy } \\
\text { development is central to } \\
\text { creating a health care system } \\
\text { that meets the needs of its } \\
\text { constituents. Political activism }\end{array}$ & $\begin{array}{l}\text { 3. Demonstrate leadership } \\
\text { in collaborative efforts to } \\
\text { develop and implement } \\
\text { policies to improve health } \\
\text { care delivery and outcomes } \\
\text { at all levels of professional } \\
\text { practice (institutional, } \\
\text { local, state, regional, } \\
\text { national, and/or } \\
\text { international). }\end{array}$ & $\begin{array}{l}\text { Spring } 2018 \\
\text { - } \quad \text { Became a student } \\
\text { member of California } \\
\text { Association of Nurse } \\
\text { Practitioners (CANP) } \\
\text { - } \quad \text { Became a member of } \\
\text { American Association } \\
\text { of Nurse Practitioners } \\
\text { (AANP) } \\
\text { - } \\
\text { Educate public on the } \\
\text { role of the DNP } \\
\text { Fall 2018 } \\
\text { - Gap analysis in Cystic } \\
\text { Fibrosis that newborn } \\
\text { screenings differ by } \\
\text { state } \\
\text { Sweat test is the gold } \\
\text { standard and should } \\
\text { obtain sweat test in }\end{array}$ \\
\hline
\end{tabular}




\begin{tabular}{|c|c|c|}
\hline $\begin{array}{l}\text { AACN DNP Essentials \& } \\
\text { NONPF Competencies }\end{array}$ & $\begin{array}{c}\text { USD DNP Program } \\
\text { Objectives }\end{array}$ & $\begin{array}{c}\text { Exemplars } \\
\text { Provide bulleted exemplars } \\
\text { that demonstrates achievement } \\
\text { of each objective }\end{array}$ \\
\hline $\begin{array}{l}\text { and the commitment to policy } \\
\text { development are central } \\
\text { elements of DNP practice. }\end{array}$ & & $\begin{array}{l}\text { place of IRT } \\
\text { (immunoreactive } \\
\text { trypsinogen test) tests } \\
\text { or conduct a CFTR } \\
\text { gene mutation testing } \\
\text { for high risk } \\
\text { populations (DNPC } \\
\text { 622) } \\
\text { Fall } 2019 \\
\text { - } \\
\text { Abstract submission } \\
\text { and acceptance for } \\
\text { poster presentation of } \\
\text { DNP Scholarly Project } \\
\text { at 2020 CANP } \\
\text { Conference (DNPC } \\
\text { 630) } \\
\text { Spring 2020 } \\
\text { Presented DNP project } \\
\text { to University of San } \\
\text { Diego and Graybill } \\
\text { Medical Group } \\
\text { Internal Medicine } \\
\text { Clinic (DNPC 630) }\end{array}$ \\
\hline $\begin{array}{l}\text { DNP Essential VI: } \\
\text { Interprofessional } \\
\text { Collaboration for Improving } \\
\text { Patient \& Population Health } \\
\text { Outcomes } \\
\text { NONPF: Leadership } \\
\text { Competencies } \\
\text { Today's complex, multi-tiered } \\
\text { health care environment } \\
\text { depends on the contributions of } \\
\text { highly skilled and } \\
\text { knowledgeable individuals from } \\
\text { multiple professions. In order } \\
\text { to accomplish the IOM }\end{array}$ & $\begin{array}{l}\text { 1. Demonstrate advanced } \\
\text { levels of clinical practice } \\
\text { within defined ethical, } \\
\text { legal, and regulatory } \\
\text { parameters in designing, } \\
\text { implementing, and } \\
\text { evaluating evidenced- } \\
\text { based, culturally } \\
\text { competent therapeutic } \\
\text { interventions for } \\
\text { individuals or aggregates. } \\
\text { 3. Demonstrate leadership } \\
\text { in collaborative efforts to } \\
\text { develop and implement } \\
\text { policies to improve health }\end{array}$ & $\begin{array}{ll}\text { Fall } 2017 \\
\text { - } & \text { Conducted evidence- } \\
& \text { based literature review } \\
& \text { regarding hypertension } \\
\text { in a primary care } & \\
\text { setting for EBP project } & \text { (DNPC 630) } \\
\text { Fall } 2018 \\
\text { - } & \text { Examined the role of } \\
& \text { genomics and } \\
\text { epigenetics in } \\
\text { identifying personal } \\
\text { risk factors and } \\
\text { modifying }\end{array}$ \\
\hline
\end{tabular}




\begin{tabular}{|c|c|c|}
\hline $\begin{array}{l}\text { AACN DNP Essentials \& } \\
\text { NONPF Competencies }\end{array}$ & $\begin{array}{c}\text { USD DNP Program } \\
\text { Objectives }\end{array}$ & $\begin{array}{c}\text { Exemplars } \\
\text { Provide bulleted exemplars } \\
\text { that demonstrates achievement } \\
\text { of each objective }\end{array}$ \\
\hline $\begin{array}{l}\text { mandate for safe, timely, } \\
\text { effective, efficient, equitable, } \\
\text { and patient-centered care in } \\
\text { this environment, health care } \\
\text { professionals must function as } \\
\text { highly collaborative teams. } \\
\text { DNPs have advanced } \\
\text { preparation in the } \\
\text { interprofessional dimension of } \\
\text { health care that enable them to } \\
\text { facilitate collaborative team } \\
\text { functioning and overcome } \\
\text { impediments to } \\
\text { interprofessional practice. } \\
\text { DNP graduates have } \\
\text { preparation in methods of } \\
\text { effective team leadership and } \\
\text { are prepared to play a central } \\
\text { role in establishing } \\
\text { interprofessional teams, } \\
\text { participating in the work of the } \\
\text { team, and assuming leadership } \\
\text { of the team when appropriate. }\end{array}$ & $\begin{array}{l}\text { care delivery and out } \\
\text { comes at all levels of } \\
\text { professional practice } \\
\text { (institutional, local, state, } \\
\text { regional, national, and/or } \\
\text { international). }\end{array}$ & $\begin{array}{l}\text { pathogenesis of } \\
\text { diseases (DNPC 622) } \\
\text { Genotyping at birth to } \\
\text { understand risks and } \\
\text { preventative factors } \\
\text { (DNPC 622) } \\
\text { - Learned how to } \\
\text { provide nutrition } \\
\text { counseling to reduce } \\
\text { obesity in adult } \\
\text { populations (NPTC } \\
\text { 602) } \\
\text { Learned how to } \\
\text { provide exercise } \\
\text { counseling to reduce } \\
\text { obesity in adult } \\
\text { populations (NPTC } \\
\text { 602) } \\
\text { Created and interpreted } \\
\text { two genograms to } \\
\text { understand and analyze } \\
\text { role of family history } \\
\text { in disease processes } \\
\text { and to understand } \\
\text { personal risk factors } \\
\text { for developing diseases } \\
\text { (DNPC 622; also } \\
\text { applies to DNP } \\
\text { Essential 3) } \\
\text { Interviewed two } \\
\text { patients to understand } \\
\text { their genetic, } \\
\text { environmental, and } \\
\text { lifestyle risk factors } \\
\text { and analyze these to } \\
\text { identify risk for disease } \\
\text { (DNPC 622; also } \\
\text { applies to DNP } \\
\text { Essential 3) }\end{array}$ \\
\hline
\end{tabular}




\begin{tabular}{|c|c|c|}
\hline $\begin{array}{l}\text { AACN DNP Essentials \& } \\
\text { NONPF Competencies }\end{array}$ & $\begin{array}{l}\text { USD DNP Program } \\
\text { Objectives }\end{array}$ & $\begin{array}{c}\text { Exemplars } \\
\text { Provide bulleted exemplars } \\
\text { that demonstrates achievement } \\
\text { of each objective }\end{array}$ \\
\hline & & $\begin{array}{l}\text { Spring } 2019 \\
\text { - Facilitated meetings } \\
\text { with patients to adhere } \\
\text { to lifestyle } \\
\text { modifications and } \\
\text { medication adherence } \\
\text { as part of the DNP } \\
\text { Project (DNP 630) } \\
\text { - } \\
\text { Learned how to } \\
\text { explain Cardiac Risk } \\
\text { Assessment score to } \\
\text { reduce incidence of } \\
\text { heart attacks and } \\
\text { strokes in adult } \\
\text { population and } \\
\text { prescribe appropriately } \\
\text { (NPTC 604) } \\
\text { Summer 2019 } \\
\text { Learned the } \\
\text { importance of POLST } \\
\text { (NPTC 535) } \\
\text { Learned about the use } \\
\text { of GoodRX to help } \\
\text { provide cheaper } \\
\text { medications to patients } \\
\text { without good } \\
\text { prescription coverage } \\
\text { (NPTC 605 \& 535) } \\
\text { Learned how to screen } \\
\text { patients for anxiety and } \\
\text { depression using } \\
\text { PHQ9 and GAD7 to } \\
\text { receive treatment faster } \\
\text { (NPTC 605) }\end{array}$ \\
\hline $\begin{array}{l}\text { DNP Essential VII: Clinical } \\
\text { Prevention \& Population } \\
\text { Health for Improving } \\
\text { Nation's Health }\end{array}$ & $\begin{array}{l}\text { 6. Employ a population } \\
\text { health focus in the design, } \\
\text { implementation, and } \\
\text { evaluation of health care } \\
\text { delivery systems that }\end{array}$ & $\begin{aligned} & \text { Fall } 2017 \\
&- \text { Completed literature } \\
& \text { review on effective } \\
& \text { pain management for } \\
& \text { hospice patients in }\end{aligned}$ \\
\hline
\end{tabular}




\begin{tabular}{|c|c|c|}
\hline $\begin{array}{l}\text { AACN DNP Essentials \& } \\
\text { NONPF Competencies }\end{array}$ & $\begin{array}{c}\text { USD DNP Program } \\
\text { Objectives }\end{array}$ & $\begin{array}{c}\text { Exemplars } \\
\text { Provide bulleted exemplars } \\
\text { that demonstrates achievement } \\
\text { of each objective }\end{array}$ \\
\hline $\begin{array}{l}\text { NONPF: Leadership } \\
\text { Competencies } \\
\text { Consistent with national calls } \\
\text { for action and with the } \\
\text { longstanding focus on health } \\
\text { promotion and disease } \\
\text { prevention in nursing, the DNP } \\
\text { graduate has a foundation in } \\
\text { clinical prevention and } \\
\text { population health. This } \\
\text { foundation enables DNP } \\
\text { graduates to analyze } \\
\text { epidemiological, biostatistical, } \\
\text { occupational, and } \\
\text { environmental data in the } \\
\text { development, implementation, } \\
\text { and evaluation of clinical } \\
\text { prevention and population. }\end{array}$ & $\begin{array}{l}\text { address primary secondary, } \\
\text { and tertiary levels of } \\
\text { prevention. }\end{array}$ & $\begin{array}{l}\text { home-based setting } \\
\text { (DNPC611). } \\
\text { - } \quad \text { Evaluated and } \\
\text { discussed current } \\
\text { health care gaps in } \\
\text { treatment of hospice } \\
\text { patients (DNPC611). } \\
\text { Summer } 2019 \\
\text { - } \quad \text { Presented Alzheimer's } \\
\text { case study and } \\
\text { discussed preventative } \\
\text { methods, differential } \\
\text { diagnosis, and } \\
\text { treatment plan (NPTC } \\
\text { 535). }\end{array}$ \\
\hline $\begin{array}{l}\text { DNP Essential VIII: } \\
\text { Advanced Nursing Practice } \\
\text { NONPF: Independent } \\
\text { Practice/Ethics Competencies } \\
\text { The increased knowledge and } \\
\text { sophistication of health care } \\
\text { has resulted in the growth of } \\
\text { specialization in nursing in } \\
\text { order to ensure competence in } \\
\text { these highly complex areas of } \\
\text { practice. The reality of the } \\
\text { growth of specialization in } \\
\text { nursing practice is that no } \\
\text { individual can master all } \\
\text { advanced roles and the } \\
\text { requisite knowledge for } \\
\text { enacting these roles. DNP } \\
\text { programs provide preparation } \\
\text { within distinct specialties that } \\
\text { require expertise, advanced } \\
\text { knowledge, and mastery in one }\end{array}$ & $\begin{array}{l}\text { 1. Demonstrate advanced } \\
\text { levels of clinical practice } \\
\text { within defined ethical, } \\
\text { legal, and regulatory } \\
\text { parameters in designing, } \\
\text { implementing, and } \\
\text { evaluating evidence-based, } \\
\text { culturally competent } \\
\text { therapeutic interventions } \\
\text { for individuals or } \\
\text { aggregates. }\end{array}$ & 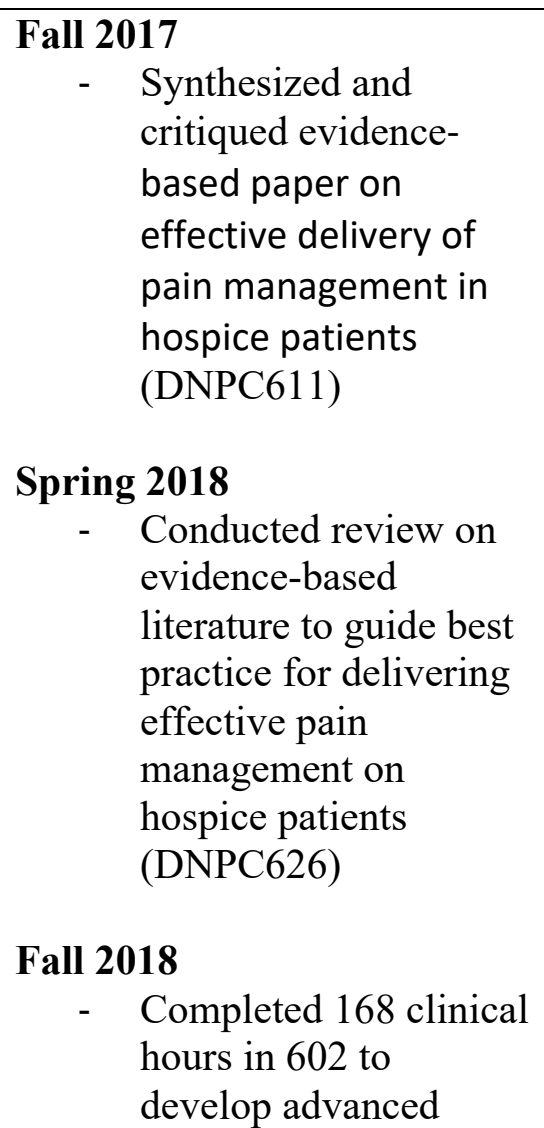 \\
\hline
\end{tabular}




\begin{tabular}{|c|c|c|}
\hline $\begin{array}{l}\text { AACN DNP Essentials \& } \\
\text { NONPF Competencies }\end{array}$ & $\begin{array}{c}\text { USD DNP Program } \\
\text { Objectives }\end{array}$ & $\begin{array}{c}\text { Exemplars } \\
\text { Provide bulleted exemplars } \\
\text { that demonstrates achievement } \\
\text { of each objective }\end{array}$ \\
\hline $\begin{array}{l}\text { are of nursing practice. A DNP } \\
\text { graduate is prepared to } \\
\text { practice in an area of } \\
\text { specialization within the larger } \\
\text { domain of nursing. }\end{array}$ & & $\begin{array}{l}\text { practice levels of } \\
\text { clinical practice } \\
\text { Conducted physical } \\
\text { health assessment in } \\
\text { clinical lab and } \\
\text { incorporated thorough } \\
\text { history intake to rule } \\
\text { out medical diagnosis } \\
\text { for perspective } \\
\text { patients. (DNPC-521) } \\
\text { Learned how to take } \\
\text { detailed health } \\
\text { histories to build } \\
\text { differential diagnoses } \\
\text { (DNPC-521; also } \\
\text { applies to Essentials } 3 \\
\text { and 8) } \\
\text { Met core competencies } \\
\text { of Advanced } \\
\text { Pathogenesis of } \\
\text { Disease (DNPC 622) } \\
\text { Contrasted principles } \\
\text { of Primary Care with } \\
\text { Acute Care to } \\
\text { understand and apply } \\
\text { the differences } \\
\text { between the two in } \\
\text { interpreting and } \\
\text { managing patient care } \\
\text { (NPTC 602) } \\
\text { Learned about Roles } \\
\text { and Responsibilities of } \\
\text { Nurse Practitioner and } \\
\text { how to interpret this } \\
\text { into future practice and } \\
\text { differentiate from } \\
\text { being an RN (NPTC } \\
\text { 602) } \\
\text { Learned Ethical } \\
\text { Principles for Nurses } \\
\text { to guide practice as an } \\
\text { NP (NPTC 602) }\end{array}$ \\
\hline
\end{tabular}




\begin{tabular}{|c|c|c|}
\hline $\begin{array}{l}\text { AACN DNP Essentials \& } \\
\text { NONPF Competencies }\end{array}$ & $\begin{array}{l}\text { USD DNP Program } \\
\text { Objectives }\end{array}$ & $\begin{array}{c}\text { Exemplars } \\
\text { Provide bulleted exemplars } \\
\text { that demonstrates achievement } \\
\text { of each objective }\end{array}$ \\
\hline & & $\begin{array}{l}\text { Spring } 2019 \\
\text { - } \\
\text { Met core competencies } \\
\text { of advanced } \\
\text { pharmacology } \\
\text { - } \\
\text { Completed } 216 \text { clinical } \\
\text { hours at Internal } \\
\text { Medicine clinic and } \\
\text { Urgent Care clinic } \\
\text { - } \\
\text { Assessed patients in } \\
\text { Endocrinologist clinic } \\
\text { (NPTC 604) } \\
\text { Assessed patients and } \\
\text { managed care plans in } \\
\text { Nursing homes (NPTC } \\
\text { 604) } \\
\text { Proficient at } \\
\text { conducting New } \\
\text { patient visits (NPTC } \\
\text { 604) } \\
\text { Proficient with having } \\
\text { conversations and } \\
\text { aiding patients in } \\
\text { filling out POLSTs } \\
\text { (NPTC 604) } \\
\text { Proficient with } \\
\text { conducting Cognitive } \\
\text { Impairment } \\
\text { Assessments for } \\
\text { Medicare patients } \\
\text { (NPTC 604) } \\
\text { Summer 2019 } \\
\text { Completed required } \\
\text { hours for both DNPC } \\
\text { 605 and NPTC 535 } \\
\text { Proficient at } \\
\text { completing cognitive } \\
\text { impairment } \\
\text { assessments for } \\
\text { Medicare } \\
\text { Reimbursement } 605 \text { ) } \\
\text { (DNPC }\end{array}$ \\
\hline
\end{tabular}




\begin{tabular}{|c|c|c|}
\hline $\begin{array}{l}\text { AACN DNP Essentials \& } \\
\text { NONPF Competencies }\end{array}$ & $\begin{array}{c}\text { USD DNP Program } \\
\text { Objectives }\end{array}$ & $\begin{array}{c}\text { Exemplars } \\
\text { Provide bulleted exemplars } \\
\text { that demonstrates achievement } \\
\text { of each objective }\end{array}$ \\
\hline & & $\begin{array}{l}\text { - Proficient with using } \\
\text { the Mini-Cog } \\
\text { Assessment tool } \\
\text { (DNPC 605) } \\
\text { - } \quad \text { Proficient with using } \\
\text { the PHQ9 Depression } \\
\text { Scale (DNPC 605) } \\
\text { - } \text { Proficient with using } \\
\text { the Generalized } \\
\text { Anxiety Disorder 7- } \\
\text { item scale (DNPC 605) } \\
\text { Proficient with } \\
\text { managing treatment } \\
\text { supplements for } \\
\text { patients requiring } \\
\text { Hemodialysis (DNPC } \\
\text { 605) } \\
\text { Learned how difficult } \\
\text { adhering to diet is for } \\
\text { patients with CKD } \\
\text { requiring hemodialysis } \\
\text { (DNPC 605) } \\
\text { Proficient with } \\
\text { administering the } \\
\text { POLST and describing } \\
\text { the POLST to patients } \\
\text { (NPTC 535) }\end{array}$ \\
\hline
\end{tabular}




\section{Appendix F}

\section{Certificates or Documentation of any Additional Certifications}

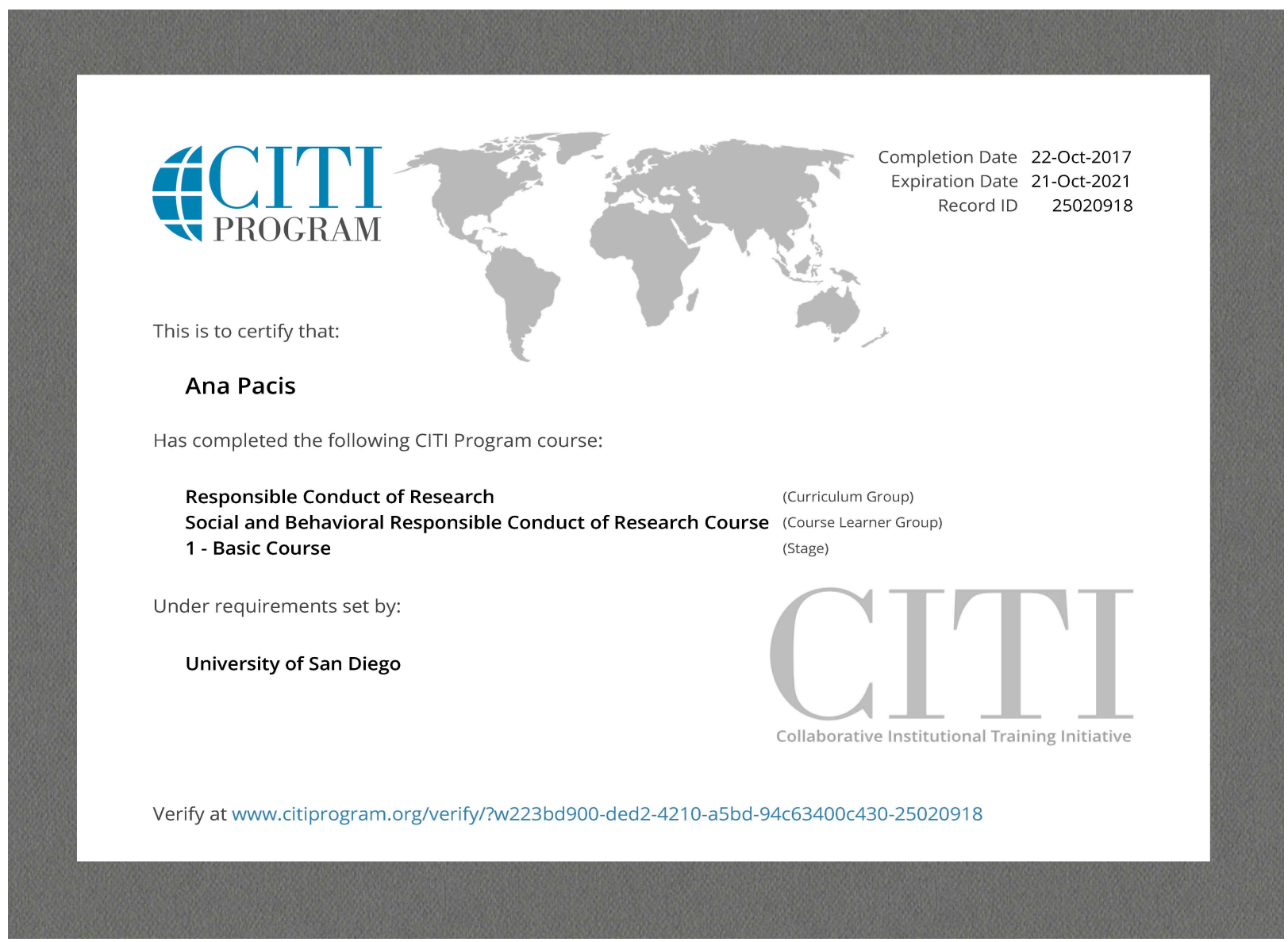




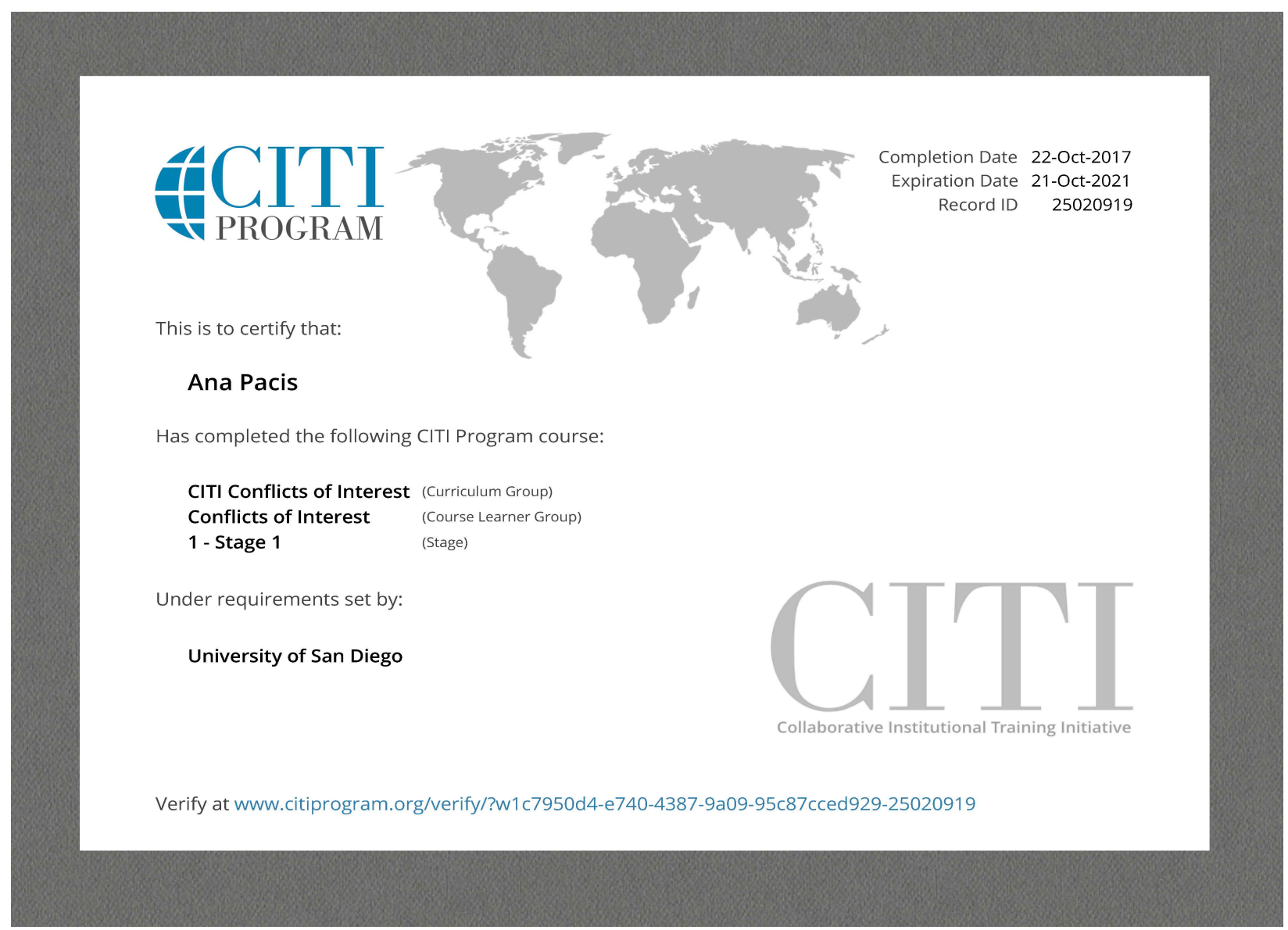

